\title{
Imperatives for Teacher Empowerment in Devising Extension Education as Part of the Holistic Curriculum for Hospitality and Tourism Domains: A Conceptual Study in Indian Context
}

\author{
Rajiv Mishra \\ Manipal University, Manipal, India \\ Mantun Kumar Singh \\ Vinoba Bhave University, Hazaribag, India
}

\begin{abstract}
The role of educator or teacher in the Indian context is circumscribed by the objective of social transformation as articulated in the Indian National Movement and later enshrined in the Preamble to the Indian Constitution, in the Fundamental Rights, and in the Directive Principles of State Policy. Extension, which is the additional dimension of professional practice among teachers at higher education, can be used as a revolutionary tool to modify the existing slogan of “education for all” to "education for all and forever”, thereby making the "lifelong education" a reality. This conceptual paper addresses the twin needs of preparing the students for individual growth as also to facilitate them to contribute to social development. It focuses on the inclusion of the measures required to be taken for providing social consciousness and sensitivity, as this happens to be a neglected part of the curriculum. The extra effort so needed to build community-based activities presupposes the requirement for professional training to be given to the hospitality and tourism educators as a continuing education initiative.
\end{abstract}

Keywords: extension education, holistic curriculum, hospitality and tourism educators, India

\section{Introduction}

The phrase "holistic curriculum" needs to be understood as a comprehensive effort to provide skills and competences required for leading the life of a responsible citizen with concern for fellow beings. Generally, job market oriented curriculum aims to provide living skills, i.e., only those skills required for earning a livelihood. The holistic curriculum concept is in conformity with the "University Grants Commission” (a statutory body of the Government of India for the coordination, determination, and maintenance of standards of university education in India) directive regarding threefold duties of a university of providing domain knowledge, getting involved in research and participating in community-oriented extension activities. The extension activities refer to those activities which are taken amidst the community set up to improve the quality of life of the members of a community. Extension education is largely the process of teaching rural people how to live better by learning ways to improve their livelihood, home, and community institutions. It is "helping people to help themselves"

Rajiv Mishra, associate professor (Hospitality \& Tourism), Welcomgroup Graduate School of Hotel Administration, Manipal University. Email: call.rajiv@yahoo.co.in; rajiv.mishra@manipal.edu.

Mantun Kumar Singh, professor, head \& dean, Faculty of Commerce \& Business Management and Director, University Department of Management, Vinoba Bhave University. 
by changing their behavior (knowledge, attitude, and skills). It is the challenge of capacity building for socio-economic development of a community; the change is carried out by formulating activities involving the community (Sanyal, 2005).

We shall examine the issues mentioned above in the light of generalized picture of contemporary higher education in India, the established aims of education as a whole, and the preamble of Indian Constitution - the last one defines the basis of Indian nationhood. It is well known that education is an instrument of change, particularly in the context of social and economic development. The links among education, employment, and economic development are long-familiar. The need for qualitative and quantitative improvements in higher education, in particular, has time and again been emphasized through India's Five-Year Plans (formulated by Planning Commission, Government of India). During the five decades of independence, India has built up a massive system of higher education; as per data (in October 2007), there are 20 central universities, 222 state universities, 109 deemed-to-be universities, and 13 institutes of national importance catering to around 110 lakh students. Although quantitative improvements have taken place in student enrolment, there is the need to increase the access to higher education, to improve the quality of teaching-learning processes, and to provide for all-round development of individuals.

According to Bertrand Arthur William Russell, the aims of education are to build vitality, courage, sensitiveness, and intelligence in the individuals. "Vitality" indicates the capability of education to cultivate a concern for the society, to create a sense of objectivity, and to enhance the power of hard work. "Courage" refers to the combination of self-respect and an impersonal outlook on life. "Sensitiveness" implies that education facilitates appropriate emotional response for the events around, which could be the precursor for any remedial action to be taken for the benefit of the society. "Intelligence" refers to actual knowledge, willingness to accept knowledge, and curiosity to look up to various sources. Another perspective is given by the "United Nations Educational, Scientific, and Cultural Organization” (UNESCO) Report of the International Commission on Education for the Twenty-First Century under the Chairmanship of Jacques Delors and published under the title "Learning: The Treasure Within". It states that education is based on four pillars: learning to know, learning to do, learning to live together, and learning to be. These four pillars are detailed as follows:

(1) Learning to know by combining a sufficiently broad general knowledge with the opportunity to work in depth on a small number of subjects. This also means learning to learn, so as to benefit from the opportunities education provides throughout life;

(2) Learning to do in order to acquire not only an occupational skill but also, more broadly, the competence to deal with many situations and work in teams. It also means learning to do in the context of young peoples' various social and work experiences which may be informal, as a result of the local or national context, or formal, involving courses, alternating study and work;

(3) Learning to live together by developing an understanding of other people and an appreciation of interdependence - carrying out joint projects and learning to manage conflicts - in a spirit of respect for the values of pluralism, mutual understanding, and peace;

(4) Learning to be so as to better develop one's personality and be able to act with ever greater autonomy, judgment, and personal responsibility. In that connection, education must not disregard any aspect of a person's potential, memory, reasoning, aesthetic sense, physical capacities, and communication skills. 
The Delors Report further states that:

Formal education systems tend to emphasize the acquisition of knowledge to the detriment of other types of learning; but it is vital now to conceive education in a more encompassing fashion. Such a vision should inform and guide future educational reforms and policy, in relation both to contents and to methods. (UNESCO, 1996, p. 97)

While discussing as to what education should achieve, the preamble of Indian Constitution has much relevance. Indian Constitution lays down the political structure for governance along with specification of citizens' rights and duties in order to ensure justice, liberty, equality, and fraternity for one and all. The educational curriculum needs to reinforce the spirit of the Constitution. Well, the above discussion can serve to sensitize us as to what should curriculum be, if it is to contribute to the wholesome development of the individuals.

\section{Objectives}

This paper is an attempt to accomplish the following objectives:

(1) To explore the need of extension activities as part of the hospitality and tourism management curriculum in India;

(2) To contemplate the integration between students and the local community by means of education and curricular advancement;

(3) To identify the desirable characteristics required by the hospitality and tourism educators to be the administrators for extension education.

\section{Context of the Study}

The paper suggests the inclusion of the measures required to be taken for providing social consciousness and sensitivity, as this happens to be a neglected part of the curriculum. It also focuses on the twin needs of preparing the students for individual growth as also to facilitate them to contribute to social development. The education should bring about holistic development of the learners including awareness about the community and the environment.

\section{Definition of Terms}

\section{Extension Activities/Education}

According to Saville (1965), the aim of all extension work is to teach rural people how to raise their standards of living, but with the minimum of assistance from government, and by their own efforts, using their own resources. It encourages progressive growth through local leadership, self-help, and civic pride. Fenley and Williams (1964) offered a succinct definition: extension education brings about improvement in a systemic way, through carefully planned and organized programmes. Extension education is voluntary, carried on out of school, directed to adults, and concerned with their livelihood. Based on sound principles of teaching and learning, it is carried on thoughtfully and systematically in an atmosphere of mutual trust and respect. Extension has three basic tasks:

(1) Disseminating useful information;

(2) Applying it to the analysis of practical problems;

(3) Helping people to use it to help themselves. 


\section{Curriculum}

The word "curriculum" comes from the Latin verb "currere” meaning to run. It actually denotes a course to be "run"; it is a metaphor for an educational course to be taught or learned. Still, the dynamic nature of curriculum is implied. Generally, the word curriculum is considered to refer to course syllabus as approved by statutory bodies. Actually, it has a wider meaning. Curriculum refers to syllabi, print and electronic media materials, teaching strategies, learning activities, assessment of the students, evaluation of syllabus, the class rooms, laboratories and library facilities, staff training and consultancy, and so on.

\section{Continuing Education}

It is the learning activities of educating or instructing the professionals by imparting up-to-date knowledge or skill in a particular area beyond their basic literacy education. It is often termed as "further education" or “adult education”. Constantly striving to learn about new and evolving knowledge or to review existing concepts and techniques is termed as “continuing education”.

\section{Review of Literature}

Hospitality and tourism has been known as the world's largest and fastest growing industry. This fast growth means that tourism constitutes a major feature of world economy and can thus act as a tool for poverty reduction in developing countries (Dieke, 2003). Several conducted studies indicate that tourism has a significant economic, social, and environmental effect at both macro and micro levels (Buckley, 2004; Gerosa, 2003; Muhanna, 2007; Torres \& Momsen, 2004). The possibility of tourism having the varying levels of flexibility to link with other sectors makes it an industry capable of pulling an economy out of poverty (Sinclair, 2003).

In order to enhance the community participation in tourism and at the same time the quality of tourism services, governments have to undertake actions for the provision of adequate educational, technical, and professional training programmes. Relly and Koch (2002) showed that tourism education should be extended to school children so that they can appreciate, right from childhood, the "wonders of nature”. Moreover, training and education can be done in several areas such as communication, environmental health, nature conservation, business, traffic safety, motor mechanics, and social work (Relly \& Koch, 2002).

Watson and Drummond (2002) commended that tourism has significant linkages with other sectors and training the people that run the industry is an integral part of its development. They reported that tourism training and education helps to improve attitudes, enthusiasm, and involvement of stakeholders in tourism development. Zhang Qiu and Lam (2004) suggested that for training to be done, a thorough environmental analysis should be done to develop a general strategic direction for human resource development. In order to create indigenous capabilities, they proposed on-the-job training, training of the trainers, and certifying educators and improving research skills.

Howell and Uysal (1987) emphasized that developing countries need professionals who have a holistic perception of the industry, people who are able to understand it as a whole, its inter-relationships, and its impact, and professionals who are able to find a way to avoid the inadequate forms of development of tourism within a country.

Throughout history, extension education has focused on topics typically associated with being an extension agent, such as program planning and evaluation. Legacy and Wells (1987) found that experienced 
agents identified program planning, evaluation, and the development of media presentations as the three most important instructional items for extension education. The most important topics for internship preparation were considered to be program planning and maintenance, committee involvement, and personal visits.

The lack of research directed towards extension education curriculum may be because the need for such a program is misunderstood. The written position descriptions for open extension positions frequently describe a desire for applicants with degrees in programmatic fields other than extension education; rarely is a degree in extension education specifically identified as desirable (National Job Bank, 2008). Adult education and volunteer management are two such skill areas closely associated with employment in cooperative extension (Franz, 2007; Schmiesing \& Safrit, 2007).

\section{Importance of Community-Oriented Activities as Part of Curriculum}

According to Scheer, Ferrari, Earnest, and Connors (2006, p. 22), “developing and revising academic programs must be an ongoing process". Extension education should not be exempt from such scrutiny. Formal extension education programs can play an integral role in developing students' job skills by providing a curriculum uniquely tailored to the competencies required of extension professionals. According to Kelly (2004, p. 4), curriculum is "the overall rationale for any educational programme".

The recruitment agencies often make a point that there is a need to improve the skills and competences of the graduates and technically/professionally trained manpower produced by the university system both at the entry level and after employment. A research survey, conducted by March Marketing Consultancy \& Research and Federation of Indian Chambers of Commerce and Industry (2007) and published in "Innovation for Quality and Relevance” at the Higher Education Summit, 2007 held at New Delhi during November 2-3, 2007, mentions that the work-related skills are most critical at the time of recruitment, while the social skills would assume importance, as the employee proceeds through the career ladder. Each industry has its own requirement of skills and competences for recruitment, and their relative importance is also different. Mostly, the university system concentrates on domain knowledge and less weight is given to other skills and competences such as soft skills, social skills, etc.. In keeping with the Preamble to the Indian Constitution, it is essential to pay attention to social skills, especially in the areas of community-oriented activities and participation in community development. Such an approach is needed to foster in students a sense of:

(1) Justice in terms of social, economic, and political aspects;

(2) Equality of status among all the components of a society;

(3) Fraternity assuring the dignity of the individual and the unity and integrity of the nation.

One of the educational purposes is to maintain its social relevance. It reflects the kind of value system the institution desires to inculcate in its students and its willingness to play the role as an instrument of change for economic development and social transformation. The community-related sensitivity needs to be developed right from schooldays and, more so, during the period of college study, as this alone could serve as the basis for lifelong social involvement. It addresses the concern for learning to live together, which is essential for peaceful coexistence in a nation and overall development. The activities help in building self-esteem by promoting a sense of concern for fellow beings, team spirit, the value of interdependence, problem-solving skills, communication power, etc.. The scheme also permits percolation of traits of tolerance, respect for local culture, understanding of the rights of individual citizens, appreciation of aesthetic beauty of unrecognized sectors, etc.. The initiative fosters a creative desire for service and empathy in the students. 
The preceding discussion shows that getting involved in community work is one of the methods of bringing about an attitudinal change, which is generally quite difficult to attain. Attitude comes under the realms of affective domain. According to Bloom's taxonomy, affective domain contains five levels: receiving, responding, valuing, organization, and characterization by value. The first level, "receiving”, refers to the willingness to receive information or to attend to particular phenomena or stimuli in the domain of feelings or emotions. Receiving also refers to actively attending to an act. The second level, "responding”, refers to active participation on the part of the student. The student is sufficiently motivated to be involved in an activity so as to gain satisfaction from working with it. The third level, "valuing", refers to the commitment to the underlying value guiding the behavior. The fourth level, "organization", is the ability to combine values (possibly fundamentally different from each other), resolving conflicts between them, and beginning to build an internally consistent value system. The individual sees how the value relates to those already held or to new ones that are coming to be held. The integration of values is less than harmonious; it is a kind of dynamic equilibrium that is dependent upon salient events at a specific point in time. The fifth level, "characterization by value", is the internalization of values that has a place in the individual's value hierarchy. The values control one's behavior for a sufficiently long period of time to develop a characteristic "life style". The behavior is pervasive, consistent, and predictable.

Significant results have been achieved through community-institution interactions in the areas of agriculture, adult literacy, child nutrition, plantation and social forestry, etc.. The community-based activities could help in spreading the messages regarding rights and duties of citizens, human rights, legal methods of redress (such as writ of habeas corpus (to prevent unlawful detention), writ of mandamus (to enforce an officer to perform his/her public duty), writ of prohibition (forbidding a lower court to continue proceedings in excess of its jurisdiction), certiorari (quashing the decision of a lower court, in case impropriety in judgment is established), quo warranto (to prevent unlawful occupation of a public position)), etc..

The community-institution interaction also benefits the educators to concretize the concepts handled in the curriculum and to give real life flavor to the teaching-learning processes. The interaction could also present a series of community-oriented research projects, which, if properly analyzed and studied, could provide methods of overcoming the problems faced by the local communities and in improving economic and social conditions in the villages and rural areas.

\section{Extension Activities as Components of Vocational Education}

Extension education is democratic in its approach. It is based on the principle of helping people to help themselves. The extension approach to economic development is, first, to develop the people, and they will develop their community, their educational and recreational institutions, their public services, and anything else they wish. That the inclusion of community-oriented activities strengthens the classification of hospitality and tourism sector-based educational initiatives as vocational courses could become evident, if we consider the views of Despotovic, Maksimovic, and Pejatovic (2004). According to them, any vocational or adult (or community) education course needs to have the following components: accessibility, integration, and partnership.

\section{Accessibility}

Capacity building should be one of the objectives of education. It must foster the necessary knowledge, skills, competencies, and values to all the stakeholders. In this knowledge era, it is an acclaimed fact that access and equity are needed to bring socio-economic development. 


\section{Integration}

The institutions should have an integrated approach of offering courses so that it could open up possibilities of widening intellectual, social, and professional development of individuals concerned. By integration, we also refer to a wide canvass of teaching-learning methods.

\section{Partnership}

The educational institutions need to play a key role in partnering with different wings of the government (such as tourism, labor, HRD, environment \& forests, etc.), hotel management and tour operators' associations, and their employees, non-governmental organizations (NGOs), labor organizations, etc.. The academic activities need to be planned with the active participation of the stakeholders.

\section{Context for the Community-Oriented Activities in Hospitality and Tourism Institutions}

The term "extension" was first used to describe adult education programs in England in the second half of the 19th century. These programs helped to extend the work of universities outside the campus and into the neighboring communities. The term was later adopted in USA, while in Britain, it was replaced with advisory services in the 20th century. Numerous other terms are used in different parts of the world to describe the same or a similar concept (Wikipedia, 2015).

The extension activities could be: (1) related to the domain of knowledge in the hospitality and tourism sectors; (2) a development-oriented activity in a community set-up, such as adult literacy, environmental protection, AIDS awareness, etc.; or (3) a training programme towards disaster or emergency management support (which would be needed during times of natural or manmade calamities). The extension activities could be planned in the form of provision of job-related skill training to the underprivileged, the unemployed, and unskilled sections of the society, destitute women, and the prisoners so that they could secure means of living. There is a need to involve other segments of society like the community leaders, prison authorities, NGOs, self-help groups, social welfare organizations, etc., to support the activities. Considering that an academic year has around 200 days of academic activities, an institution is left with considerable time to fulfill its social obligations. The academic expertise, infrastructural facilities, etc. are valuable institutional resources to meet the demands of skill training in non-formal wings of hospitality and tourism sectors. We shall illustrate community-based activities related to domain knowledge in hospitality and tourism disciplines:

(1) Hospitality, for instance, deals with one of the three basic needs of human beings, namely food. The implication is that a large scope exists in selecting community development-oriented activities. The activities could be of the following types: skill training camp from any of the hospitality-related fields such as food production, food \& beverage service, housekeeping, bakery and confectionery. Owners and staffs of roadside dhabas (food stalls) and motels could be trained on hygiene and sanitation aspects of food, balanced diet, budgeting and account-keeping, legal literacy, etc.;

(2) As regards tourism sector, the extension activities can be carried out in rural tourism, agri/farm tourism, ecotourism, etc.. In the present context, we shall consider only those related to ecotourism. In the case of ecotourism, the communities offer natural and manmade resources: the flora, fauna, local artisans and local unemployed manpower, etc., while the institutions can provide expertise, planned activities, awareness level, and enabling programmes. Organizing extension work can be of use in understanding the socio-economic and cultural concerns and conflicts as well as issues related to development of local communities in the backdrop of ecotourism locations. It could also sensitize the students against the negative effects of ill-managed systems like 
physical displacement of persons, violation of human rights, conflicts in control of land-use, damage to the environment, etc.. Two of the conflict situations are stated below:

(a) The pressure on Andaman and Nicobar islands is evident from the fact that as per 2001 census, the population is around four lakhs but more than one lakh tourists have visited during 2005; with much less accommodation available, the upcoming resorts pose problems in the light of "Coastal Regulation Zone" (CRZ) rules $^{1}$, which apply for coastal stretches of sea, bays, estuaries, creeks, rivers, and backwaters, all influenced by the tidal action. For such a fragile and delicate environment, ecologically conscious tourists are needed;

(b) Goa, for instance, has a $105 \mathrm{~km}$ long coastal line and much of it comes under the purview of CRZ rules; environmentalists have raised the issue that construction activity has proceeded in violation of CRZ rules in order to have a sea view. Another report mentions that in some of the localities, the local people expressed concern over illegal land conversions, since their claim to natural resources is eroded.

Some of the success stories of community run ecotourism initiatives are to be brought to the notice of students. Examples are available from Sikkim (Dzongu Ecotourism Committee managing trekking), West Bengal (local villagers running Community Tourism at Sundarbans), and Kerala (local adivasis with traditional knowledge of forest and wildlife participating in ecotourism programme in Periyar Tiger Reserve).

\section{Successive Stages for the Community-Based Activities}

The start is to be done with planning of the series of activities to be undertaken. The sequence of actions could be examined as follows.

\section{Carrying Out Need Analysis}

An elaborate exercise has to be undertaken to gather necessary information about the characteristics of the target clientele, local needs, cultural aspects, community or segment leaders to be consulted, etc.. Opinion from experts, peer groups, NGOs, and the target group will also be of help in organizing the activities.

\section{Matching the Activities With Resource Requirement}

A list of activities planned and the resources available from the institution, community, and support groups is to be prepared. The gaps in resources are to be identified along with remedial actions. Monetary requirements should be modest and within reach. The list should take into account the student and target population size which are going to be involved and the time factor as well. Prior training also needs to be planned for preparing the students with effective communication and interpersonal skills. Motivation strategy needs to in-built. As part of the activities, debate, music, humor session, dramatization, folk dances, etc. could also be included to provide a variety in which the students, teachers, and the target group could participate.

\section{Team Formation and Execution}

The activities should be classified and group responsibilities are to be assigned towards each of the components. Due weight must be given for planning, execution, and evaluation of the activities. Even at the time of formulating the objectives, the performance indicators should also be incorporated into the scheme. The college students may exhibit distinct areas of intelligence, such as linguistic, logical, spatial, kinesthetic, musical, emotional, interpersonal, and naturalistic. While building teams, these aspects need to be kept in mind for effective execution of the plan.

\footnotetext{
${ }^{1}$ The Ministry of Environment and Forests, Government of India had issued the CRZ Notification in 1991 under the Environment Protection Act 1986, with the aim to provide comprehensive measures for the protection and conservation of our coastal environment.
} 


\section{Preparing Evaluation Report}

Towards the end of the activities, the evaluation of the effectiveness of the activities is to be carried out. It gives valuable lessons as to how best the activities can be modified. The documentation could help in providing an improved model during future initiatives.

\section{Showcasing the Skills Developed}

In case specific skill inculcation programme is carried out with a segment of the community, it is worthwhile helping the group in exploring or suggesting suitable employment opening so that an honorable livelihood could be secured. In certain cases, organizing community-based events or exhibitions could also be a morale booster for the trained group. Christ College, Bangalore provided training to a batch of street children in hospitality-related activities, which resulted in employment to a few of them.

\section{Student Certification}

As an incentive and morale booster, the students need to be given certificate for participation; in case of innovative contribution, it can be suitably rewarded.

\section{Desirable Characteristics of Educators as Administrators of Extension Activities}

In a developing society like India, institutions of higher learning have also an active role in evolving and maintaining a highly functional and dynamic link with the community. Creation of excellence is not the only goal of such institutions; it is perceived as an additional legitimate objective of an institution of higher education in a country like India to assume the status of a pivotal or nodal agency or a nucleus of the overall development of the community in which such institution exists. Educator in such institutions therefore has an additional duty of making available his or her expertise for the development of various sectors of the community. Increasingly, educators or teachers are also expected to use their expertise in matters of national importance like nation building.

The values ascribed to academic profession by “The National Commission on Teachers” (Government of India, 1983) have much significance in running extension activities:

(1) Acquisition and transmission of knowledge;

(2) Social relevance of knowledge;

(3) Establishing link with the society through extension work;

(4) Continuous efforts to upgrade knowledge;

(5) Freedom of inquiry;

(6) Desire for excellence;

(7) Willingness to collaborate;

(8) Critically analyzing the events;

(9) Willingness to take criticism;

(10) Initiating the innovative activities;

(11) Possessing skills for planning and guiding the activities;

(12) Motivating the students and the communities;

(13) Favorable attitude to execute the activities;

(14) Having problem-solving skills;

(15) Knowledge of socio-economic and cultural status and sensitivities of the communities involved. 


\section{Implications for Implementation: Continuing Education as an Empowering Tool for the Hospitality and Tourism Educators to Facilitate Taking Up Extension-Based Work}

An extension educator must simultaneously wear multiple hats, that of a teacher, guide, friend, and philosopher. To be a successful extension educator, one must have not only a sound knowledge and understanding of the subject, but also an interest and ability to work for and with community people. The profession, while challenging, can also be very satisfying.

Knowledge in every field is fast changing. There is a continuous need to develop the skills and competences. Constantly striving to learn about new and evolving knowledge or to review existing concepts and techniques is termed as "continuing education". The continuing education gives an opportunity for the educators to interact with colleagues and serves to open up knowledge areas unvisited. It promotes a higher level of professionalism in the concerned domain worldwide. For attaining necessary skills or imbibing socio-economic and cultural knowledge and to be able to plan appropriate extension activities, the educators may need to resort to continuing education methods. Taking up online study or distance learning, attending group discussion, workshops or seminars or conferences or summer schools or meetings (of learned societies) or training programmes as also taking up a short-term course could be some of the continuing education methods. No more can teachers confine their role within the four walls of educational institutions. They have to feel the pulse of the community and try to help them solve their problems. They are to be social engineers who can mould the destiny of the nation, in and outside the classrooms.

\section{Conclusion and Recommendation}

There is a lack of proper attention, awareness, and interest in extension education. The linkage between teachings, research, and extension is weak, particularly because extension is still not well recognized and used properly as the other two academic functions of the university (Warner, Christenson, Dillman, \& Salant, 1996). The knowledge generated by research often gets obsolete by the time it is disseminated through education/teaching and finally trickles down to community members and practitioners through extension due to big lapse of time. The universities should consider this problem seriously and should reform their academic activities to strengthen the links between research, teaching, and extension. E-extension or Internet-aided extension networks have to be materialized as nerve centers for dissemination of technical know-how. There is a need of change in extension from transfer of technology mode to technology application mode by initiating group approach and community group's participatory approach of extension activities. Inclusion of community-based organizations, stakeholders in extension formation and training of self-help groups, and extension through rural location-specific knowledge center would serve the need of present extension service. Extension education and training needs to focus on need-based, problem-solving, and skill-based vocational enterprises for self-employment for rural youth. There is a dire need to establish linkages among extension education, continuing education, non-formal education, distance education, and vocational education, so that each supports and strengthens the efforts of the other and vice versa. It is necessary to mention here that the formation of commodity-specific extension kiosk on all niche tourism products (vizagri tourism, rural tourism, farm tourism, village tourism, etc.) and value addition enterprises are required. Distance education and technology enabled learning for community-entrepreneurs need to be explored and strengthened through television, radio, interactive audio and video systems, besides print and programmed learning materials which would be the distinguishing feature of extension teaching and learning process. 


\section{References}

Buckley, R. C. (2004). Skilled commercial adventure: The edge of tourism. In T. V. Singh (Ed.), New horizons in tourism (pp. 37-48). Oxford: CAB International.

Despotovic, M., Maksimovic, I., \& Pejatovic, A. (2004). Methodology of curriculum development in vocational education and training and adult education. Vocational Education and Training Reform Programme. Retrieved from http://www.vetserbia.edu.rs/policy_and_strategy\%20_papers.htm

Dieke, P. U. C. (2003). Tourism in Africa’s economic development: Policy implications. Management Decisions, 41(3), $287-295$.

Fenley, J. M., \& Williams, S. K. T. (1964). Background for extension work, ministry of agriculture, and natural resources. Extension Training Manual Bulletin, No. 3.

Franz, N. (2007). Adult education theories: Informing cooperative extension's transformation. Journal of Extension, 45(1). Retrieved from http://www.joe.org/joe/2007February/a1.shtml

Gerosa, V. (2003). Pro-poor growth strategies in Africa. Tourism: A viable option for pro-poor growth in Africa? Paper prepared for the Economic Commission for Africa Expert Group Meeting, Kampala.

Government of India. (1983). National commission on teachers II. New Delhi: Government of India.

Howell, R., \& Uysal, M. (1987). Tourism education for developing countries. Tourism Management, 8(1), 62-64.

Kelly, A. V. (2004). The curriculum: Theory and practice (5th ed.). London: Sage Publications.

Legacy, J., \& Wells, J. (1987). A national study of recommended curricula for extension education methods classes and student internship programs. Journal of Agricultural Education, 28(4), 9-14.

March Marketing Consultancy \& Research and Federation of Indian Chambers of Commerce and Industry. (2007). Innovation for quality and relevance. Research Survey by March Marketing Consultancy \& Research, Hyderabad and Federation of Indian Chambers of Commerce and Industry, New Delhi, published in the Volume on the Higher Education Summit held at New Delhi, November 2-3, 2007.

Muhanna, E. (2007). The contribution of sustainable tourism development in poverty alleviation of local communities in South Africa. Journal of Human Resources in Hospitality and Tourism, 6(1), 37-67.

National Job Bank. (2008). Jobs in extension, outreach, research, \& higher education. Retrieved from http://jobs.joe.org/search_list.php

Relly, P., \& Koch, E. (2002). National responsible tourism guidelines for the South African tourism sector: Application of the guidelines to the nature-based tourism sector. Case Study Assessment, Jackalberry Lodge, Thornybush Game Reserve.

Sanyal, B. C. (2005). The role of higher education in obtaining EFA goals with particular focus on developing countries. Paper prepared for the UNESCO Forum on Higher Education, Research, and Knowledge, p. 12.

Saville, A. H. (1965). Extension in rural communities. London: Oxford University Press.

Scheer, S. D., Ferrari, T. M., Earnest, G. W., \& Connors, J. J. (2006). Preparing extension professionals: The Ohio State University's model of extension education. Journal of Extension, 44(4). Retrieved from http://www.joe.org/joe/2006august/a1p.shtml

Schmiesing, R. J., \& Safrit, R. D. (2007). 4-H youth development professionals' perceptions of the importance of and their current level of competence with selected volunteer management competencies. Journal of Extension, 45(3). Retrieved from http://www.joe.org/joe/2007june/rb1p.shtml

Sinclair, D. (2003). Developing indigenous tourism: Challenges for the Guianas. International Journal of Contemporary Hospitality Management, 15(3), 140-146.

Torres, R., \& Momsen, J. H. (2004). Challenges and potential for linking tourism and agriculture to achieve pro-poor tourism objectives. Progress in Development Studies, 4(4), 294-318.

UNESCO. (1996). Learning: The treasure within. Report to UNESCO of the International Commission on Education for the Twenty-First Century chaired by Jacques Delors. Paris: UNESCO.

Warner, P. D., Christenson, J. A., Dillman, D. A., \& Salant, P. (1996). Public perception of extension. Journal of Extension, 34(4). Retrieved from http://www.joe.org/joe/1996august/a1.php

Watson, S., \& Drummond, D. (2002). A strategic perspective to human resource development in Scottish tourism. International Journal of Contemporary Hospitality Management, 14(5), 253-254.

Wikipedia. (2015). Agricultural extension. The Free Encyclopedia. USA: The Wikimedia Foundation, Inc.. Retrieved from http://en.wikipedia.org/wiki/Agricultural_extension

Zhang Qiu, H., \& Lam, T. (2004). Human resources issues in the development of tourism in China: Evidence from Heilongjiang province. International Journal of Contemporary Hospitality Management, 16(1), 45-51. 